\title{
TERAPI IMUNOSUPRESAN PADA PASIEN ANEMIA APLASTIK DENGAN PERDARAHAN GUSI: MENYEMBUHKAN ATAU MEMPERPARAH?
}

\author{
Revi Nelonda*, Eliza Kristina Munthe*, Riani Setiadhi ${ }^{* *}$
}

Keywords: Aplastic anemia, gingival bleeding, gingival hiperplasia, immunosuppressant

\begin{abstract}
Background: Aplastic anemia (AA) is a hematologic disorder characterized by hypoplastic bone marrow and peripheral pancytopenia. The main symptoms are fatigue and bleeding. In the oral cavity, gingival bleeding is the common complaint. Case Management: A 18-year-old female patient referred from internal medicine department due to swelling of palate since 2 days before that interrupted eating activity. She routinely consumes Sandimun $® 100 \mathrm{mg}$ tablets. A $2 \times 1 \mathrm{~cm}$ black blood clot in anterior hard palate and ulcerative lesion at dorsal tongue regio 45 surrounded by necrotic area were found on intra oral examination. Patient was diagnosed with necrotizing ulcer-related neutropenia accompanied by AA-associated hemorrhagic bullae in the hard palate. Patient treated with mouthwash containing $0.1 \%$ hyaluronic acid and $1 \%$ feracrylum.

Discussion: Immunosuppressant is the AA gold standard therapy. Cyclosporine (CsA) as imunosupressant is common drug to prevent T cells from attacking stem cells in bone marrow. The side effects of CsA is gingival hiperplasia.

Conclusions: Gingival bleeding and gingival hiperplasia due to thrombocytopenia and the use of cyclosporine are vicious circles that need to be aware. With comprehensive management, good oral conditions will be obtained, therefore the quality of life can increase.
\end{abstract}

\section{PENDAHULUAN}

Anemia aplastik (AA) adalah gangguan perdarahan yang serius dan sering fatal, ditandai oleh kegagalan sel prekursor hematopoietik pada sumsum tulang untuk menghasilkan eritrosit, granulosit, dan trombosit yang mengakibatkan pansitopenia, ${ }^{1,2,3}$ dengan kejadian tahunan sekitar 1-2 kasus baru per 1.000.000 individu per tahun. ${ }^{1,3}$

Anemia aplastik ditandai dengan gejala kelelahan, pendarahan karena trombositopenia dan terjadinya infeksi berulang akibat neutropenia. ${ }^{2}$ Neutropenia merupakan kondisi yang terjadi saat jumlah total neutrofil lebih rendah dari 2000 x 106 liter. Manifestasi neutropenia dalam rongga mulut berupa ulser nekrotik dengan dasar putih atau keabu-abuan tanpa adanya tanda-tanda inflamasi. ${ }^{4}$ Trombositopenia didefinisikan sebagai kondisi dengan jumlah trombosit dibawah 150.000/mm ${ }^{3}$.5,6 Manifestasi oral yang sering terjadi pada kondisi trombositopenia yaitu adanya satu atau lebih petekie hemoragik serta perdarahan spontan pada gingiva. ${ }^{5}$

Tatalaksana AA pada dasarnya terdiri dari 3 yaitu: transplantasi sel punca, terapi imunosupresif (IST) dan perawatan suportif. IST menjadi pengobatan standar untuk AA khususnya pada pasien yang tidak dapat dilakukan SCT, ${ }^{3,7,8}$ dengan antithmyocyte globulin (ATG), antilymphocyte globulin (ALG) dan cyclosporine (CsA) merupakan pilihan yang sering digunakan dengan keberhasilan seki$\operatorname{tar} 50-60 \% .^{7,89,10}$ Namun CsA mempunyai efek samping pada rongga mulut yaitu terjadinya

*Oral Medicine Residency Program, Faculty of Dentistry, Universitas Padjadjaran, Bandung Indonesia, ${ }^{* *}$ Oral Medicine Department, Faculty of Dentistry, Universitas Padjadjaran, Bandung Indonesia

Korespondensi: revinelonda@gmail.com

ODONTO Dental Journal. Volume 6. Special Issue 1. April 2019 
hiperplasia gingiva, dengan insidensi sebesar $8-81 \% .{ }^{11,12,13}$ CsA menginduksi terjadinya hiperplasia gingiva melalui efek stimulasinya terhadap munculnya transforming growth factor-beta1 (TGF- $\beta 1$ ) dan kolagen, ${ }^{12}$ sehingga mengakibatkan infiltrasi sel plasma, peningkatan jumlah sel inflamasi (makrofag) dan peningkatan derajat vaskularisasi. ${ }^{13,14}$

Hiperplasia gingiva yang disertai perdarahan gusi pada pasien $\mathrm{AA}$ akan menyebabkan pasien semakin kesulitan untuk menjaga oral hygiene.

Tatalaksana komprehensif dalam menciptakan kondisi mulut yang sehat bagi pasien AA sangat diperlukan untuk memutus mata rantai ini. Dokter gigi diharapkan dapat menciptakan kondisi rongga mulut yang baik sehingga dapat meningkatkan kualitas hidup pasien AA.

\section{LAPORAN KASUS}

Pasien perempuan, 19 tahun dirujuk dari Departemen IImu Penyakit Dalam RSHS dengan keluhan gusi bengkak dan perdarahan pada gusi, ia diketahui menderita anemia aplastik sejak 6 bulan. Beberapa hari terakhir pada langit-langit terdapat bengkak seperti bekuan darah, yang awalnya kecil dan lama-kelamaan menjadi besar. Pemeriksaan intra oral pada palatum terlihat massa seperti bekuan darah berwarna ungu kehitaman pada regio anterior ukuran $2 \times 1 \mathrm{~cm}$, konsistensi kenyal dan sakit jika disentuh. Lateral lidah kanan terdapat lesi ulseratif, dasar kecoklatan dengan tepi nekrotik irregular. Pada mukosa bukal regio 45 terdapat lesi ulseratif nekrotik berwarna putih kekuningan ukuran diameter $\pm 3 \mathrm{~mm}$ (Gambar 1). Ulser nekrotik oral terkait

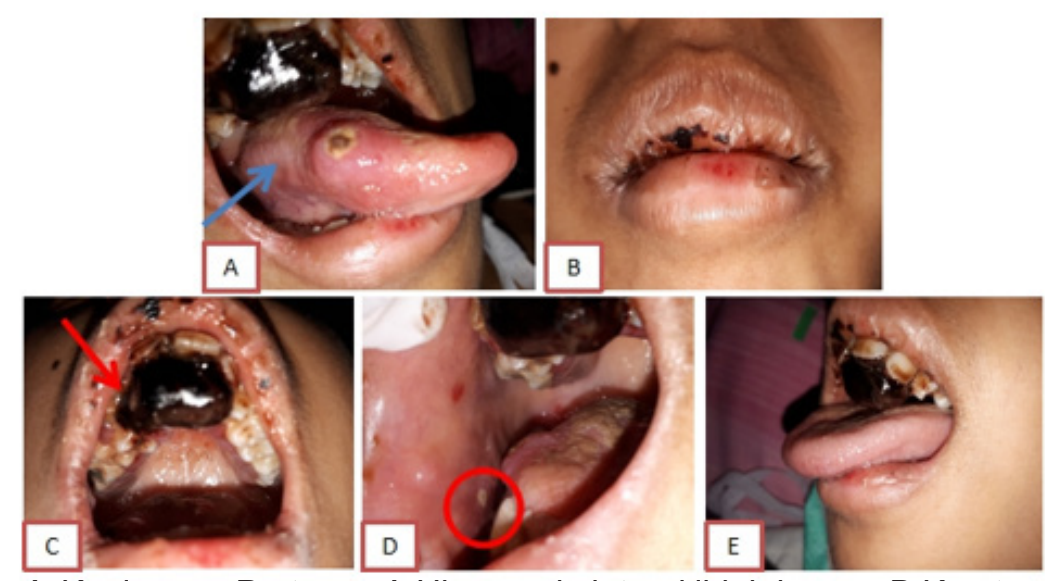

Gambar 1. Kunjungan Pertama. A.Ulser pada lateral lidah kanan; B.Krusta pada bibir; C. Hemoragik bula pada palatum; D.Ulser pada mukosa bukal kanan; E. Tampak samping hemoragik bula.

Tabel 1. Hasil Pemeriksaan Hematologi.

\begin{tabular}{|c|c|c|c|c|c|c|c|c|c|}
\hline Pemeriksaan & $09 / 4$ & $13 / 4$ & $15 / 4$ & $16 / 4$ & $24 / 4$ & $26 / 4$ & $27 / 4$ & $28 / 4$ & Satuan \\
\hline Haemoglobin & 6,0 & 8,2 & 7,4 & 7,4 & 5,4 & 4,4 & 7.0 & 7,0 & $\mathrm{~g} / \mathrm{dL}$ \\
\hline Leukosit & 1,31 & 0,98 & 0,68 & 0,89 & 1,38 & 1,29 & 0,63 & 0,69 & $10^{3} / \mu \mathrm{L}$ \\
\hline Hematokrit & 17,4 & 232,8 & 21,5 & 20,9 & 15,7 & 12,9 & 20,2 & 20,5 & $\%$ \\
\hline Trombosit & 38 & 23 & 9 & 26 & 2 & 11 & 14 & 27 & Ribu/ $/ \mathrm{L}$ \\
\hline $\begin{array}{l}\text { Neutrofil } \\
\text { Batang }\end{array}$ & 0 & 0 & 0 & 0 & 0 & 0 & 0 & 0 & $\%$ \\
\hline $\begin{array}{l}\text { Neutrofil } \\
\text { Segmen }\end{array}$ & 2 & 3 & 2 & 3 & 2 & 3 & 2 & 4 & $\%$ \\
\hline
\end{tabular}


neutropenia pada lateral lidah regio 45-46 dan mukosa bukal regio 45, disertai hemoragik bula terkait kondisi AA pada 1/3 palatum anterior ditegakkan sebagai diagnosis. Empat hari kemudian, bekuan darah yang terdapat pada $1 / 3$ palatum anterior telah lepas, sehingga ia dapat melakukan aktivitas makan dengan lebin leluasa, walaupun lesi ulseratif yang dikeliling daerah nekrotik pada lateral lidah masih ada (Gambar 2).

Dua belas hari kemudian, perdarahan aktif pada rongga mulut terjadi kembali. (Gambar 3). Pasien mengalami perbaikan dengan perawatan yang komprehensif dari Departemen IImu Penyakit Dalam dan Penyakit Mulut 5 hari berikutnya. Perdarahan aktif pada rongga mulut sudah tidak terlihat. Pasien diperbolehkan pulang dan dirujuk ke bagian periodonsia untuk perawatan jaringan periodontalnya (Gambar 4). Satu hari sebelum jadwal kontrol ke bagian IImu Penyakit Mulut dan bagian Periodonsia, pasien meninggal dunia.

Tatalaksana pasien dilakukan melalui pendekatan farmakologis dan non-farmakologis dari bagian IImu Penyakit Dalam dan bagian IImu Penyakit Mulut. Tatalaksana far- makologis dari bagian IImu Penyakit dalam terdiri dari imunosupresan berupa Sandimun $®$ $2 \times 100 \mathrm{mg}$ per oral, paracetamol 3x500mg, GCSF 1x300mg, cefepim 3x2gr intravena, nystation oral suspension $4 \times 1 \mathrm{ml}$ dan chlorhexidine gluconate $0,2 \%$. Sandimun $®$ merupakan obat yang rutin dikonsumsi pasien sejak diketahui menderita AA dengan dosis 2x100mg. Pada tanggal 27 April 2018, dosis Sandimun ${ }^{\circledR}$ dinaikkan menjadi 2x200 mg, untuk mengatasi kondisi hematologis yang tidak stabil. Pasien juga mendapatkan beberapa kali transfusi trombosit dan sel darah merah (Tabel 2) sebagai tatalaksana non-farmakologis.

Tatalaksana farmakologis dari bagian IImu Penyakit Mulut berupa pemberian 1\% ferracrylum, untuk dikumur 3 kali sehari dan dikompres pada hemoragik bula dipalatum. Obat kumur yang mengandung asam hyaluronic 0,025\% diberikan untuk mengobati lesi ulseratif yang ada di lidah. Obat kumur mengandung asam traneksamat $5 \%$ diberikan jika $1 \%$ ferracrylum susah didapatkan. Chlorhexidine gluconate $0,1 \%$ diberikan untuk menjaga kebersihan rongga mulut.


Gambar 2. Kontrol 13 April 2018. A. Hemoragik bula sudah lepas; B. Ulser pada lateral lidah (tampak frontal); C. Ulser pada lateral lidah (tampak lateral)
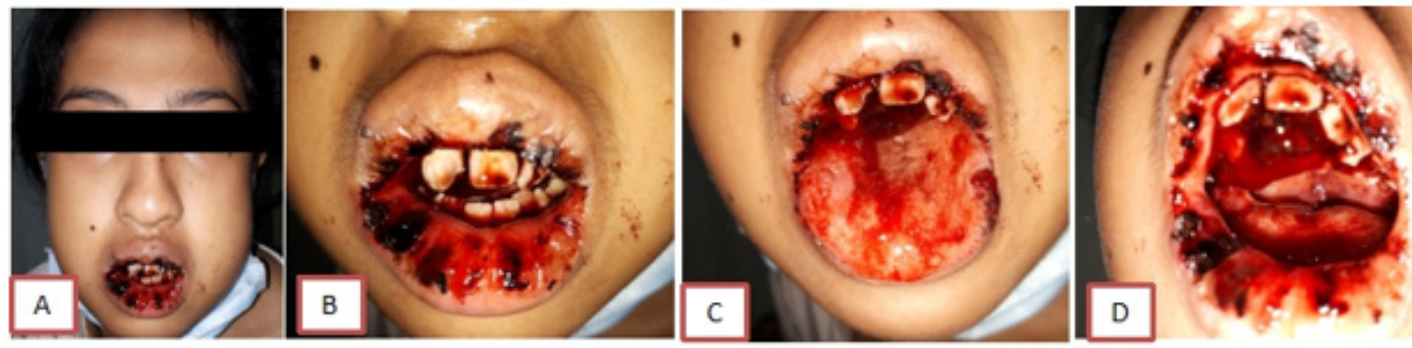

Gambar 3. 12 hari kemudian. A-D Perdarahan spontan terjadi pada rongga mulut. 


\begin{tabular}{lcccc}
\multicolumn{5}{c}{ Tabel 2. Transfusi Darah } \\
\hline Jenis Transfusi & $\mathbf{1 1 / 0 4}$ & $\mathbf{1 2 / 0 4}$ & $\mathbf{1 5 / 0 4}$ & $\mathbf{2 5 / 0 4}$ \\
\hline Trombosit & 6 & 4 & 4 & 12 \\
Sel darah merah & - & - & - & 4 \\
\hline
\end{tabular}
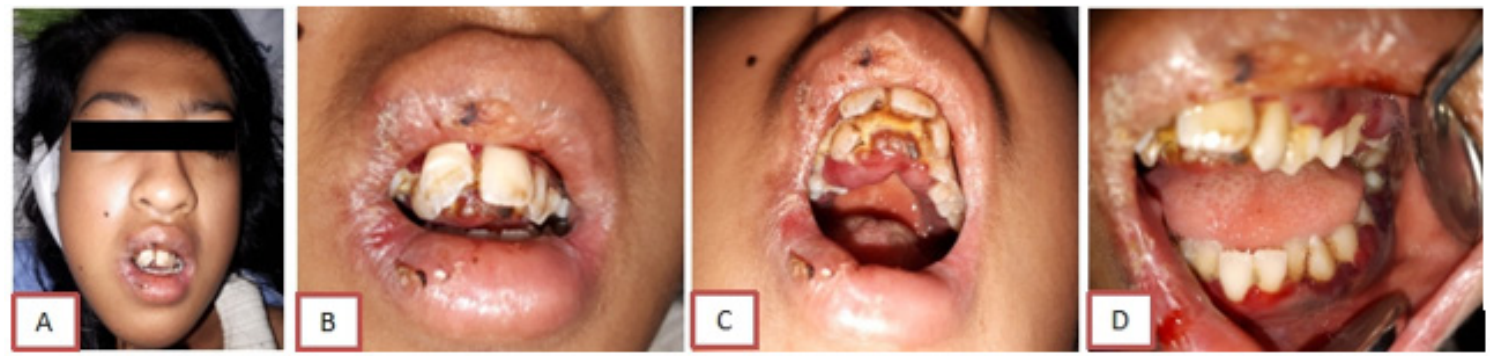

Gambar 4. Kontrol terakhir. A-D Perdarahan spontan telah berhenti. Hiperplasia gingiva terlihat pada seluruh gingiva

\section{DISKUSI}

Anemia aplastik (AA) merupakan penyakit gangguan perdarahan serius ditandai dengan hiposeluler sumsum tulang yang memproduksi sel punca hematopoiesis sehingga mengakibatkan berkurangnya produksi eritrosit, granulosit dan trombosit biasanya disebut dengan pansitopenia, ${ }^{15,16,17}$ dengan insidensi penyakit 2-6 kasus/1 juta penduduk per tahun. ${ }^{18,19}$

Gambaran klinis AA berhubungan secara langsung dengan kondisi pansitopenia, yaitu suatu keadaan setidaknya terjadi 2 kondisi berupa kondisi anemia, trombositopenia atau neutropenia. Anemia dapat menyebabkan gejala klasik seperti fatique, takikardia, sakit kepala, pusing, kram kaki atau insomnia, perdarahan kulit dan mukosa, epistaksis, atau bahkan gangguan penglihatan. Trombositopenia akan menyebabkan perdarahan pada mukosa seperti epistaksis, perdarahan subkonjungtiva, perdarahan gusi dan lain-lain. Neutropenia akan menyebabkan infeksi berupa ulserasi mulut, febris dan sepsis atau syok septik. ${ }^{17,20}$ Gambaran klinis ini sesuai dengan gambaran klinis yang dirasakan oleh pasien pada kasus ini, yaitu mudah lelah, hingga terkadang pingsan, pusing, perdarahan spontan pada gingiva dan ulser pada rongga mulut. Gambaran klinis saja tidak cukup untuk menegakkan diagnosis definitif AA. Pemeriksaan darah lengkap yang memperlihatkan kondisi pansitopenia dan aspirasi sumsum tulang mutlak diperlukan. Pemeriksaan aspirasi sumsum tulang akan menunjukkan gambaran sel yang sangat kurang dengan banyak jaringan ikat dan jaringan lemak, aplasi sistem eritropoetik, granulopoetik dan trombopoetik. Pemeriksaan aspirasi sumsum tulang pada pasien dilakukan 3 bulan yang lalu, sehingga meyakinkan bahwa pasien menderita AA.

Perdarahan oral sering dianggap sebagai hal yang tidak berbahaya, namun manifestasi oral ini dapat merefleksikan kemungkinan timbulnya perdarahan di tempat lain, seperti di otak, paru-paru dan saluran pencernaan, yang jika terjadi akan berakibat fatal dan menyebabkan kematian. Brennan et al (2001) mengevaluasi prevalensi manifestasi oral pada 79 pasien dengan AA ditemukan pada $27 \%$ perdarahan gingiva spontan dan hiperplasia gingiva dilaporkan pada $16 \%$ pasien. ${ }^{21}$ Keluhan perdarahan gusi dan bengkak berwarna kehitaman pada palatum menjadi penyebab utama pasien dirujuk ke Departemen IImu Penyakit Mulut. Perdarahan gusi spontan yang terjadi dise- 
babkan kondisi trombositopenia terlihat dari jumlah trombosit antara $2000 / \mu \mathrm{L}-38.000 / \mu \mathrm{L}$. Pasien juga diberi transfusi berupa trombosit dan sel darah merah dari bagian Penyakit dalam untuk mengatasi kondisi hematologis yang tidak stabil (Tabel 1).

Tatalaksana AA terdiri dari 3 bentuk, yaitu transplantasi sumsum tulang, terapi imunosupresif (IST) dan terapi suportif. AA yang di obati IST terbukti mampu bertahan hidup lebin lama. ${ }^{22}$ Diantara semua IST, cyclosporine (CsA) merupakan pilihan yang sering digunakan, ${ }^{7,8}$ dan terbukti dapat mengobati kelainan perdarahan hingga $70 \% .{ }^{16}$ Cyclosporine A (CsA) merupakan sebuah calcineurin inhibitors yang menghambat produksi interleukin-2 (IL-2) oleh sel-T serta menghambat proliferasi sel-T dari respon oleh IL-2, dengan dosis awal pada hari pertama $10 \mathrm{mg} / \mathrm{kg}$ berat badan. ${ }^{7}$ Walaupun CsA merupakan pilihan imunosupresan yang sering digunakan untuk mengobati $A A$, namun CsA mempunyai efek samping pada rongga mulut yaitu terjadinya hiperplasia gingiva, dengan insidensi sebesar 8-81\%.11,12,13 Efek samping CsA dalam menyebabkan hiperplasia gingiva pertama kali dilaporkan oleh Seymour pada tahun $1983,{ }^{23}$ dengan insidensi sebesar $40 \%-70 \%$, dan meningkat pada kondisi oral hygiene yang buruk. ${ }^{15,24} \mathrm{CsA}$ menginduksi terjadinya hiperplasia gingiva melalui efek stimulasinya terhadap munculnya transforming growth factor-beta1 (TGF- $\beta 1$ ) dan kolagen, ${ }^{12}$ mengakibatkan infiltrasi sel plasma, peningkatan jumlah sel inflamasi (makrofag) dan peningkatan derajat vaskularisasi. ${ }^{13}$ Faktor yang mempermudah timbulnya hiperplasia gingiva yaitu respon berlebih terhadap iritan lokal berasal dari akumulasi plak dan bekuan darah sehingga kebersihan rongga mulut menjadi buruk. ${ }^{25}$ Secara histopatologi, jaringan gingiva di infiltrasi oleh sel-sel leukosit immatur pada in- flamasi kronik, namun dapat juga memperlihatkan leukosit matur. Pembuluh darah setempat akan tertekan oleh infiltrat sehingga jaringan gingiva mengalami edema dan degenerasi. ${ }^{26}$

Tatalaksana farmakologis pasien dari bagian ilmu penyakit dalam berupa Sandimun ${ }^{\circledR}$ dengan dosis $3 \times 100 \mathrm{mg}$. Sandimun $\AA$ merupakan salah satu obat imunosupresif golongan CsA. Pemberian siklosporin mempunyai efek samping hiperplasia gingiva. Pada pasien, diperburuk oleh keberadaan kalkulus disemua regio rahang atas dan rahang bawah, sehingga membuat pasien kesulitan untuk membersihkan rongga mulut. Insiden penyakit periodontal pada pasien dengan gangguan perdarahan diketahui lebih tinggi disebabkan kurang efektifnya pasien dalam menjaga kebersihan mulut dan perawatan gigi karena takut perdarahan oral aktif kembali. ${ }^{27,28,29}$ Ketika terjadi hiperplasia gingiva, pasien akan kesulitan membersihan rongga mulut, sehingga kontrol terhadap plak dan kalkulus menjadi tidak adekuat. Perdarahan akibat reaksi inflamasi pada gingiva ini bertambah berat jika kondisi sistemik pasien memburuk seperti terjadi penurunan trombosit terkait AA.

Tatalaksana farmakologis dari bagian IImu Penyakit Mulut adalah 1\% ferracrylum sebagai topikal hemostatik. Ferracrylum adalah golongan garam besi yang tidak lengkap (II dan III) dari asam poliakrilat, bertindak sebagai agen hemostatik topikal dan bersifat antimikroba biasa digunakan dalam pengendalian oozing pada berbagai tindakan yang bertendesi terjadinya perdarahan. ${ }^{30}$ Cara kerjanya yaitu melalui aktivasi trombin, kemudian menyebabkan konversi fibrinogen menjadi fibrin dan membentuk gumpalan. ${ }^{30}$ Setelah pemberian obat kumur $1 \%$ ferracrylum dengan cara dikumur dan dikompres sebanyak 3 kali dalam sehari, hemoragik bula pada pasien terlepas 
sehingga pasien dapat melalukan aktivitas makan dengan baik. Sediaan 1\% ferracrylum sukar ditemukan di Indonesia. Sebagai alternatif, pasien diberikan obat kumur mengandung asam tranexamat sebagai hemostatik topikal. Asam tranexamat merupakan agen yang biasa digunakan dalam penatalaksanaan gangguan perdarahan dan merupakan terapi adjuvant untuk mendukung terjadinya proses pembentukan bekuan pada setiap gangguan perdarahan. ${ }^{27}$ Obat kumur asam tranexamat terbukti menciptakan konsentrasi terapeutik saliva apabila digunakan sebagai obat kumur mulut. ${ }^{31} \mathrm{Se}-$ lain pemberian obat kumur asam tranexamat, pasien juga diberikan obat kumur chlorhexidine gluconate $0,1 \%$, dengan tujuan untuk mengurangi peradangan dan inflamasi gingiva. ${ }^{27,31}$

Untuk tatalaksana non farmakologis, perawatan supportif pada pasien AA berupa dukungan psikologis dari keluarga dan teman dekat sangatlah penting. ${ }^{32}$

\section{KESIMPULAN}

Imunosupresan merupakan alternatif pilihan terapi bagi pasien $\mathrm{AA}$ yang tidak bisa di melakukan transplantasi sumsum tulang. Namun pilihan ini mempunyai efek samping merugikan terhadap rongga mulut, yaitu timbulnya masalah periodontal berupa hiperplasia gingiva. Kondisi ini dapat bertambah parah apabila terdapat iritan lokal berupa bekuan darah yang sering ditemukan pada pasien dengan perdarahan gusi spontan, seperti pasien AA. Untuk memutus mata rantai ini, diperlukan tatalaksana yang komprehensif dalam menciptakan kondisi mulut sehat bagi pasien AA.

\section{DAFTAR PUSTAKA}

1. Rai A, Vaishali V, Naikmasur VG. Aplastic anemia presenting as bleeding of gingiva: Case report and dental considerations. SAUDI J Dent Res [Internet]. 2015;4-7.

2. Jalaeikhoo $\mathrm{H}$, Khajeh-mehrizi A. Immunosuppressive Therapy in Patients with Aplastic Anemia : A Single-Center Retrospective Study. PLoS One. 2015;1-10.

3. Passweg JR. Immunosuppressive treatment for aplastic anemia : are we hitting the ceiling ? Haematologica. 2009;94(3):2-4.

4. Franch AM, Esteve CG, Pérez MS. Oral manifestations and dental management of patient with leukocyte alterations. 2011;3(1).

5. Khammissa RAG, Fourie J, Masilana A, Lawrence S, Lemmer J, Feller L. Oral manifestations of thrombocytopaenia. Saudi Dent J. 2017.

6. De AAS. Oral manifestation of thrombocytopenia in immunosuppressed patient - Report of case. 2016;1(June 2012):87-90.

7. Damodar S. Immunosuppressive Therapy for Aplastic Anaemia History of IST for Aplastic. 2015;16-20.

8. Young NS, Bacigalupo A, Marsh JCW. Aplastic Anemia: Pathophysiology and Treatment. Biol Blood Marrow Transplant. 2010;16(1):S119-25.

9. Frickhofen $\mathrm{N}$, Heimpel $\mathrm{H}$, Kaltwasser JP, Schrezenmeier $\mathrm{H}$. Antithymocyte globulin with or without cyclosporin A: 11-year follow-up of a randomized trial comparing treatments of aplastic anemia. Blood. 2003;101(4):1236-42.

10. Anemia A, Young NS. Antithymocyte Globulin and Cyclosporine for Severe Aplastic Anemia. J Am Med Assoc. 2003;289(9):5-10.

11. Seema G. Immunosuppressant Drugs: Role in Periodontium. 2016;6(2).

12. Martin L. Cyclosporin A-induced gingival overgrowth is not associated with myofibroblast transdifferentiation. 2010;1(2):182-8.

13. Gogalniceanu D. Gingival overgrowth induced by immunosuppressive treatment with cyclosporine A and mycophenolate mofetil in a patient with kidney transplant. Int J Med Dent. 2013;3(3):183-7.

14. Isyanto, Abdulsalam M. Masalah Pada Tata Laksana Anemia Aplastik Didapat. Sari Pediatr. 2005;7(1):26-33.

15. Puhar I. Severe Generalized Periodontitis in a Patient with an Aplastic Anemia: a 5 Year Follow-up Case Report. acta Stomatol croat. 2015;49(2):151-7.

16. Adeyemo T, Adediran A, Akanmu A, Adeyemo W, Akinbami AJ. Orofacial manifestations of hematological disorders: Anemia and hemostatic disorders. Indian J Dent Res. 2011;22(3):454.

17. Isabel ANA, Ramos B. Aplastic anemia-from pathophysiology to diagnosis, maagement and treatment. 2015;

18. Montané E, Ibáñez L, Vidal X, Ballarín E, Puig R, García N, et al. Epidemiology of aplastic anemia: A prospective multicenter study. Haematologica. 2008;93(4):518-23.

19. Young NS, Calado RT, Scheinberg P. Current concepts in the pathophysiology and treatment of 
aplastic anemia. Blood J. 2006;108(8):2509-20.

20. Brennan MT, Sankar V, Baccaglini L, Pillemer SR, Kingman A, Nunez $O$, et al. Oral manifestations in patients with aplastic anemia. Oral Surg Oral Med Oral Pathol Oral Radiol. 2001;92(5):503-8.

21. Glick M, Murray W. Burket's Oral Medicine. 2015.

22. Scheinberg $P$, Young NS. How I treat acquired aplastic anemia. Blood J. 2012;120(6):1185-97.

23. Ponnaiyan D, Jegadeesan V. Cyclosporine A: Novel concepts in its role in drug-induced gingival overgrowth. 2015;499-506.

24. Aral CA, Dilber E, Aral K, Sarıca Y, Sivrikoz ON. Management of Cyclosporine and Nifedipine-Induced Gingival Hyperplasia. 2015;12-5.

25. Nelmi Wahyuni. Peran Dokter Gigi Dalam Mendeteksi Dini Leukemia Melalui Manifestasinya Di Rongga Mulut (Laporan Kasus). USU e-Repository (C) 2008. 2008;

26. Cooper CL, Loewen R, Tsiporah Shore. Gingival Hyperplasia Complicating Acute Myelomonocytic Leukemia. Journal_Canadian_Dental_Association. 2000;66(2):78-9.

27. Gupta A, Epstein JB, Cabay RJ. Bleeding Disorders of Importance in Dental Care. 2007;73(1).

28. Sarmast ND, Quevedo MJG, Wang HH, Herrera ERG. Acute Local Spontaneous and Profuse Gingival Hemorrhage during Neoadjuvant Treatment with Paclitaxel and Trastuzumab. 2016;4-7.
29. Darby I. Drugs and gingival bleeding. Aust Prescr. 2006;29(6):154-5.

30. Laddha AK, Mulla M, Sharma SS, Lahoti BK. A prospective comparison of topical feracrylum citrate versus adrenaline as haemostatic agent in hypospadias surgery in children. 2014;

31. Nuvvula S, Gaddam K, Kamatham R. Efficacy of tranexamic acid mouthwash as an alternative for factor replacement in gingival bleeding during dental scaling in cases of hemophilia: A randomized clinical trial. Contemp Clin Dent. 2014;5(1):49.

32. Marsh JCW, Ball SE, Cavenagh J, Darbyshire P, Dokal I, Gordon-smith EC, et al. Guidelines for the diagnosis and management of aplastic anaemia. 2012;(May):43-70. 